$\left.\begin{array}{c}\text { LOCAL WISDOM, 9 (1): 51-60, 2017 } \\ \text { Local Wisdom Scientific Online Journal } \\ \text { ISSN: 2086-3764 }\end{array}\right) \begin{array}{r}\text { wiSDOM } \\ \mathrm{w}\end{array}$

\title{
Tipo-morfologi Kawasan dan Permukiman Desa Oro-oro Ombo Kota Batu
}

\author{
Budi Tri Wijaya
}

Jurusan Arsitektur lingkungan binaan Fakultas Teknik Universitas Brawijaya malang Jln. MT. Haryono 169, Malang 65145

\begin{tabular}{|c|c|}
\hline & Abstract \\
\hline \multirow[t]{2}{*}{$\begin{array}{l}\text { Keywords: } \\
\text { Oro-oro ombo } \\
\text { village, spatial, tipo- } \\
\text { morfolgy, the } \\
\text { influence of tourist } \\
\text { activities. }\end{array}$} & $\begin{array}{l}\text { The Batu City of tourism city, will develop and growing with the advent of time and on the change. } \\
\text { The development tourist object continous increased, causing the quality of global environment. } \\
\text { Oro-oro ombo village located in Batu city tourism. We have caused the changes tourism in the area } \\
\text { of the village. The purpose of examining the case is to know how to build a place that is a factor that } \\
\text { influences the change. The study case used the tipology- morfology approach. Data collection } \\
\text { method of literature data direct observation. To know physical characters the region and non } \\
\text { physical. Data analysis methods using method descriptive analysis to describe the condition of } \\
\text { being perceived respondent about variables that set a model research. The change of Oro-oro ombo } \\
\text { village because of the influence of tourist activities start since } 2008 \text { raises the occurrence of change } \\
\text { in good physical condition or non-physical. The physical aspect residential compound Oro-oro } \\
\text { ombo village can be seen the context of the scale of macro and micro. On aspect of non-physical, } \\
\text { social culture and socil economy community affecting the settlement pattern. }\end{array}$ \\
\hline & Abstrak \\
\hline $\begin{array}{l}\text { Kata Kunci: } \\
\text { Desa Oro-oro } \\
\text { Ombo, Tata ruang, } \\
\text { Tipo-Morfologi, } \\
\text { pengaruh aktivitas } \\
\text { wisata }\end{array}$ & $\begin{array}{l}\text { Kota batu sebagai kawasan kota wisata, akan berkembang dan tumbuh seiring dengan } \\
\text { perkembangan waktu serta pada perubahannya. Perkembangan kota terus berlanjut, } \\
\text { pembangunan objek-objek wisata terus-menerus mengalami peningkatan, menyebabkan } \\
\text { kualitas lingkungan global. Desa Oro-oro ombo yang terletak di kawasan wisata kota } \\
\text { Batu, terdapatnya objek wisata mengakibatkan perubahan di kawasan desa tersebut. } \\
\text { Tujuan mengkaji kasus ini untuk mengetahui objek-objek tipe bangunan dan perubahan } \\
\text { tata ruang desa yang terjadi akibat aktivitas sebagai suatu kawasan wisata serta factor- } \\
\text { faktor yang mengetahui perbedaan perubahannya. Kajian kasus ini menggunakan } \\
\text { pendekatan tipologi- morfologi. Metode pengumpulan data berupa literatur data hasil } \\
\text { observasi langsung. Untuk mengetahui karakter fisik kawasan dan non fisik. Metode } \\
\text { analisis data menggunakan metode analisis deskriptif untuk menggambarkan kondisi } \\
\text { yang dirasakan responden mengenai variabel yang dijadikan model penelitian. } \\
\text { Berubahnya desa Oro-oro ombo karena pengaruh aktivitas wisata mulai sejak tahun } \\
2008 \text { menimbulkan terjadinya perubahan baik kondisi fisik ataupun nonfisik. Aspek } \\
\text { fisik kawasan permukiman desa Oro-oro ombo dapat dilihat dari konteks skala makro } \\
\text { dan mikro. Pada aspek nonfisik, sosial budaya dan sosial ekonomi masyarakat yang } \\
\text { mempengaruhi pola permukiman. }\end{array}$ \\
\hline
\end{tabular}

@ 2017 The Authors. Published by GKAK UNMER Malang

*Corresponding Author: yayak543@gmail.com, Tlp (0341)571260, Fax (0341)580801 


\section{PENDAHULUAN}

Perkembangan kota Batu di mulai sejak abad ke-1, Wilayah batu dan sekitarnya dikenal sebagai tempat peristirahatan bagi kalangan keluarga karena wilayahnya daerah pegunungan dengan kesejukan udara yang nyaman, juga didukung oleh keindahan oleh pemandangan alam sebagai ciri khas daerah pegunungan. Sebagaimana layaknya wilayah pegunungan,Batu dan sekitarnya juga memiliki panorama alam yang indah dan berudara sejuk. Tentunya hal ini akan menarik minat bangsa lain untuk mengunjungi dan meikmati sebagai kawasan pegunungan yang mempunyai daya tarik tersendiri. Untuk itulah di awal abad ke-19 batu berkembang menjadi daerah tujuan wisata, sehingga akhirnya banyak villa-villa terbangun sebagai tempat peristirahatan.

Kota Wisata Batu merupakan salah satu kota di Jawa timur yang memiliki daya tarik wisata yang cukup kuat. Terdapatnya objek wisata mengakibatkan perubahan desa Oro-oro ombo. Desa Oro-oro ombo yang awalnya berkarakteristik masyarakat agraris mengalami perubahan sebagai akibat industralisasi pariwisata. Desa Oro-oro ombo berubah menjadi kawasan wisata pada tahun 2008. Masyarakat pada desa ini memanfaatkan potensi alam untuk dijadikan sebagai obyek wisata. Perkembangan desa ini dengan adanya objek wisata ini menimbulkan banyak perubahan yang terjadi pada kawasan desa. Dengan adanya kajian mengenai tipologi dan morfologi kawasan permukiman ini, diharapkan dapat memunculkan tipologi kawasan dan proses morfologinya baik secara fisik maupu nonfisik. Sehingga dari kajian tersebut dapat ditemukan faktor-faktor penyebab terbentuknya kawasan permukiman di desa Oro-oro ombo Batu, kaitan sosial budaya dan sosial ekonomi yang mempengaruhi karakteristik kawasan permukiman tersebut. Rumusan masalah kajian kasus yaitu, berubahnya desa Oro-oro ombo karena terdapatnya objek wisata yang mulai sejak tahun 2008 menimbulkan terjadinya perubahan baik kondisi fisik ataupun nonfisik. Dan Perubahan yang terjadi akibat adanya obyek wisata mengalami perbedaan beberapa tipe bangunan pada kawasan tersebut. Tujuan mengkaji kasus ini untuk mengetahui beberapa objek-objek tipe bangunan dan mengelompokan berdasarkan kesamaan. Dan perubahan tata ruang yang terjadi pada desa ini akibat aktivitas sebagai suatu kawasa wisata serta factor-faktor yang mengetahui perbedaan perubahan.

\section{METODE}

Pada kajian kasus ini menggunakan pendekatan tipologi-morfologi. Metode pengumpulan data berupa literatur baik yang berasal dari buku, jurnal, artikel ilmiah, proceeding maupun sumber lain yang berkaitan dengan teori mengenai tipologi dan morfologi arsitektur lokasi dan objek yang dipilih, dan juga data hasil observasi langsung. Hal pertama yang dilakukan adalah Mengetahui karakter fisik kawasan dan mengidentifikasi karakteristik non fisik atau sosial budaya.

Metode analisis data menggunakan metode analisis deskriptif untuk menggambarkan kondisi yang dirasakan responden mengenai variabel yang dijadikan model penelitian. Kemudian dilakukan analisis mengenai tipologi dan morfologi kawasan dengan menggunakan teori Lynch mengenai permukiman sebagai acuan untuk mengidentifikasi kawasan makro. Pada tahap awal akan terlebih dahulu menganalisis tipologi kawasan secara makro dan dan mikro pada bangunan, kemudian selanjutnya pada tahapan proses morfologi kawasan secara makro dan juga mikro terkait variable yang digunakan. Kemudian menarik kesimpulan mengenai karakteristik tipomorfologi kawasan ini berserta faktor-faktor penyebab yang membentuk karakteristik kawasan. 
Variabel penelian sebagai berikut.

\begin{tabular}{|c|c|c|}
\hline $\begin{array}{c}\text { Bidang } \\
\text { Penelitian }\end{array}$ & $\begin{array}{c}\text { Fokus } \\
\text { Penelitian }\end{array}$ & Variable \\
\hline Aspek Fisik & Morfologi & Perkembangan \\
(Tata Ruang) & Kawasan & kawasan \\
\cline { 3 - 3 } & & $\begin{array}{c}\text { Fungsi } \\
\text { Bangunan }\end{array}$ \\
\cline { 3 - 3 } & & Jalan \\
\cline { 3 - 3 } & & Guna Lahan \\
\cline { 3 - 3 } & Morfologi & Organisasi \\
& Ruang & Ruang \\
\cline { 3 - 3 } & & $\begin{array}{c}\text { Hubungan } \\
\text { Ruang }\end{array}$ \\
\cline { 3 - 3 } & & Bentuk Ruang \\
\cline { 3 - 3 } & & Fungsi Ruang \\
\hline Aspek Non & Aktivitas & Sosial \\
Fisik (social & Penduduk & Ekonomi \\
\cline { 3 - 3 } & & Sosial Budaya \\
\hline
\end{tabular}

\section{Lingkup Kawasan Sejarah Lokasi Studi}

Oro oro Ombo, pada zaman dahulu adalah merupakan sebuah tempat dimana terdapat area atau lahan tanah kosong [oro oro;bhs Jawa] yang cukup luas [ombo;bhs Jawa] dan digunakan sebagai tempat berkumpul para Petinggi Kerajaan Mataram untuk beristirahat dalam perjalanannya. Geografis wilayah Oro oro Ombo yang terletak di kaki lereng Gunung Panderman dengan panorama yang indah serta hawanya yang sangat sejuk saat itu menjadikan daya tarik tersendiri bagi siapapun yang sedang dalam perjalanan untuk beristirahat di tempat ini, maka pada akhirnya daerah ini dinamakan "Desa Oro oro Ombo." Oleh seorang yang bernama" Brodjodento " yang tak lain adalah salah satu petingi kerajaan Mataram.

Luas wilayah Desa Oro-oro Ombo adalah sebesar $11.969 \mathrm{~km} 2$, dan membentang luas dari kaki gunung Panderman hingga ke bagian bawah daerah pusat Kota Batu. Secara geografis wilayah Desa Oro-oro Ombo terletak pada ketinggian $<700-730$ meter di atas permukaan air laut Topografi atau wilayah bentang alam yang ada di Desa ini adalah perbukitan atau pegunungan $\pm 363 \mathrm{Ha}$, dengan kesuburan tanahnya yang sedang \pm 363
Ha, sedangkan curah hujan rata-rata $2889 \mathrm{~mm} /$ th dengan batas wilayah:

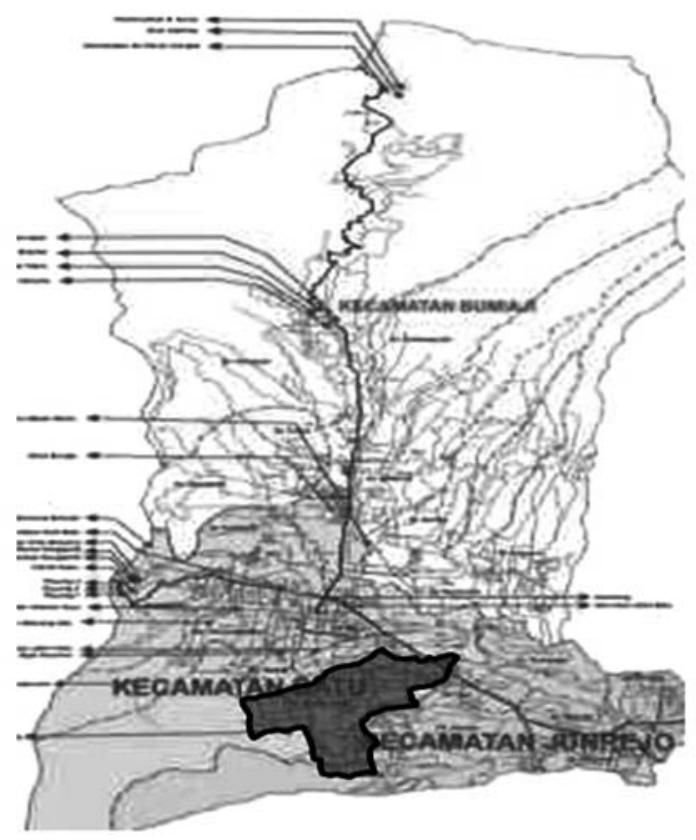

Gambar 1. Kota Batu

(Sumber: google maps) Diakses 27 Maret 2017

- Sebelah utara : Kelurahan Sisir dan kelurahan Temas,

- Sebelah selatan : Desa Tlekung,

- Sebelah barat

Panderman dan : Menjulang Gunung

- Sebelah timur : Desa Beji



Gambar 2 Peta Desa Oro-oro Ombo

(Sumber: google/desaoro-oroombo) Diakses 27 Maret 2017 


\section{Kebijakan Pemerintah \& Peraturan Perwilayahan}

Standar Perencanaan dan Perancangan terdapat pada Peraturan daerah Kota Batu nomor 7 tahun 2011 tentang Rencana Tata Ruang Wilayah Kota Batu tahun 2010 - 2030 Dalam peren- canaan dan perancangan.

Bab V Tentang Recana Struktur Ruang Pusat lingkungan sebagaimana dimaksud dalam pasal 13 ayat (3) huruf c merupakan pusat pelayanan skala lingkungan di Bagian Wilayah Kota;

- Guna Lahan

Desa Oro-oro Ombo sebagai pusat lingkungan berfungsi sebagai pusat pemerintahan skala desa pusat perdagangan pendukung pariwisata dan pusat kegiatan wisata modern dilengkapi dengan kawasan perdagangan pendukung pusat pariwisata buatan, jasa pendukung pariwisata berupa villa dan halte wisata.

- Jumlah lantai dan ketinggian

Terdapat hampir $100 \%$ bangunan di Oro-oro ombo memiliki ketinggian 15-20 meter.

- $\mathrm{KDB}, \mathrm{KLB}, \mathrm{TLB}$ dan GSB

Secara umum penggunaan lahan di kawasan merupakan pusat pariwisata, jasa, dan vila. Rata-rata memiliki KDB 60-70\%. Umumnya KLB berkisar antara 0,6-2,1. Dan TLB 1-3 lantai. Sempadan bangunan berkisar 7 meter.

\section{Kajian Pustaka Tipologi}

Tipologi berasal dari satu suku kata yaitu Tipo yang berarti pegelompokan dan Logis yang mempunyai arti ilmu atau bidang keilmuan. Berarti Tipologi merupakan ilmu yang mempelajari pengelompokan suatu benda dan makhluk secara umum berdasarkan tipe atau jenis (Wikipedia). Sedangkan secara harfiah Tipologi adalah suatu ilmu yang mempelajari segala sesuatu tentang tipe. Tipologi arsitektur dalam hal ini tipologi bangunan erat berkaitan dengan suatu penelusuran elemen-elemen pembentuk suatu sistem objek bangunan atau arsitektural. Elemen-elemen teresbut merupakan organism arsitektural terkecil yang berkaitan untuk mengidentifikasi tipologi dan untuk membentuk suatu sistem, elemen-elemen tersebut mengalami suatu proyek komposisi, baik penggabungan, pengurangan, stirilisasi bentuk dan sebagainya.

Tipologi (typologi) merupakan satu skema klasifikatori, yang merupakan hasil dari proses mentipe-kan (typication) yang mengacu pada ciri-ciri tipikal kualitas individu atau orang, benda-benda, atau peristiwa, oleh karenanya tipologi merupakan suatu kategori niskal yang mempunyai acuan empirikal. Menurut Sulistijowati (1991:12), pengenalan tipologi akan mengarah pada upaya untuk mengkelaskan, mengelompokkan atau mengklasifikasikan berdasar aspek atau kaidah tertentu. Aspek tersebut antara lain:

1). Fungsi (meliputi penggunaan ruang, struktural, simbolis, dan lain-lain);

2). Geometrik (meliputi bentuk, prinsip tatanan, dan lain-lain); dan

3). Langgam (meliputi periode, lokasi atau geografi, politik atau kekuasaan, etnik dan budaya, dan lain-lain).

Bagian bangunan dan arsitektur yang paling mudah untuk dilihat adalah bagian wajah bangunan atau yang lebih dikenal dengan sebutan façade bangunan. Bagian façade bangunan ini juga sering disebut tampak, kulit luar ataupun tampang bangunan, karena façade bangunan ini merupakan yang paling sering diberi penilaian oleh para pengamat tanpa memeriksa terlebih dahulu keseluruhan bangunan baik di keseluruhan sisi luar bangunan, maupun pada bagian dalam bangunan. Penilaian tersebut tidak hanya dilakukan oleh para arsitek tetapi juga masyarakat awam (Prijotomo 1987:3).

Dapat disimpulkan bahwa tipologi adalah suatu kegiatan untuk mempelajari objek-objek arsitektural dan mengelompokan dalam suatu tipe berdasarkan kesamaan dalam hal-hal tertentu yang 


\section{Tipo-morfologi Kawasan dan Permukiman Desa Oro-Oro Ombo Kota Batu}

Budi Tri Wijaya

dimiliki objek arsitektural tersebut. Dari hasil analisa tipologi tersebut kita dapat menentukan tipe dari objek daan menempatkan secara benar dalam kasifikasi tipe yang sudah ada. Tipologi dapat membantu menerangkan suatu tipe beradasarka karakteristik yag dimiliki setiap objek arsitektural.

\section{Morfologi}

Secara harfiah, morfologi berarti ilmu tentang bentuk. Morfologi terdiri dari dua suka kata yaitu morf yang berarti bentuk dan logos yang berarti ilmu. Secara sederhana morfologi berarti ilmu yang mempelajari produk bentuk-bentuk fisik secara logis. Morfologi merupakan pendekatan dalam memahami bentuk logis sebuah kota sebagai produk perubahan sosio-spatial. Disebabkan karena setiap karakteristik sosial-spatial di setiap tempat berbeda-beda maka istilah morfologi sangat erat kaitannya dengan istilah tipologi.

Menurut Rose (1976) dalam Ronald (2008) bahwa morfologi merupakan studi hasil tentang perubahan bentuk, hubungan dan struktur dari objek. Dalam perubahan bentuk biasanya melalui proses evaluasi dengan waktu yang cukup lama. Satuan kajian untuk mengklasifikasikan bentukbentuk menurut tipe dan aturan-aturannya.

Menurut Herbert lingkup kajian morpologi kota ditekankan pada bentuk bentuk fisikal dari lingkungan kekotaan yang dapat diamati dari kenampakannya meliputi unsur (1) sistem jalanjalan yang ada, (2) blok-blok bangunan baik daerah hunian ataupun bukan (perdagangan/industri), (3) bangunan bangunan individual. Sedangkan (Smailes, 1955) menekankan lingkup kajian morfologi meliputi (1) penggunaan lahan (land use), (2) pola-pola jalan (street) dan (3) tipe-tipe bangunan (architectural style of buildings $\mathcal{E}$ their design). Dari sinilah pertama kalinya muncul istilah Townscape.

Dapat disimpulkan bahwa Morfologi adalah studi hasil tentang perubahan bentuk, hubungan dan struktur dari objek.

\section{Landasan Teori}

Tipomorfologi sebagai metode untuk mengetahui bentuk-bentuk arsitektural. Menurut Moudon (1994), tipomorfologi adalah pendekatan untuk mengungkapkan struktur fisik dan keruangan yang mana studi tersebut merupakan gabungan dari studi tipologi dan morfologi. Menurut Schultz (1980) dikonsepkan bahwa tipomorfologi mendeskripsikan kelompok objek berdasarkan atas kesamaan sifat-sifat dasar yang berupa memila ataupun mengklasifikasikan bentuk keragaman dan kesamaan jenis.

Untuk mengungkapkan struktur fisik suatu lingkungan suatu kawasan melalui tipomorfologi dapat ditinjau dari beberapa teori seperti tinjauan teori mengenai kawasan permukiman dari Lynch yang berkaitan dengan pengidentifikasian berbagai elemen struktur fisik sejumlah kota yang menjadikan kota-kota tersebut menjadi dapat digambarkan dan dibayangkan citranya. Lynch (1960) menyimpulkan bahwa ada lima kategori elemen yang dipergunakan orang untuk menstrukturkan gambaran kognisi dari sejumlah tempat. Elemen-elemen dasar tersebut adalah:

a. Tanda-tanda yang Mencolok (Landmark)

Landmark adalah elemen penting dari bentuk kota karena mereka membantu orang-orang untuk mengarahkan diri dan mengenal suatu daerah dalam kota. Sebuah landmark yang Baik adalah elemen yang berbeda tetapi harmonis dalam latar belakangnya.

b. Jalur-jalur Jalan (path)

Adalah jalur-jalur sirkulasi yang digunakan oleh orang untuk melakukan pergerakkan. Sebuah kota mempunyai jaringan jalur utama (major routes) dan sebuah lingkungan (minor routes).

c. Titik Temu antar Jalur (nodes)

Sebuah nodes adalah pusat aktivitas yang sesungguhnya adalah sebuah tipe dari landmark tetapi berbeda karena fungsinya yang aktif. 
Nodes dapat juga berupa perempatan atau pertigaan.

d. Batas-batas Wilayah (edges)

Edges membedakan antara wilayah yang satu dengan wilayah yang lainnya, misalnya daerah pemukiman dibatasi oleh sungai, daerah pertokoan dibatasi oleh gerbang-gerbang tol menuju tempat parkir, atau pagar lapangan golf yang luas membatasi wilayah perindustrian terhadap wilayah pemukiman.

e. Distrik (district)

Distrik adalah wilayah-wilayah homogeny yang berbeda dari wilayah- wilayah lain, misalnya pusat perdagangan ditandai oleh bangunan-bangunan bertingkat dengan lalulintas yang padat dan daerah-daerah kantorkantor kedutaan besar negara asing ditandai oleh rumah- rumah besar dengan halamanhalaman luas serta jalan-jalan lebar bertipe boulevard.

\section{HASIL DAN PEMBAHASAN}

Analisis tipologi kawasan dengan menggunakan teori Lynch.

\section{Landmark (tengaran)}

Kawasan ini memiliki Landmark berupa gunung yang memang kawasan ini berada di bawah lereng gunung panderman. Dan tugu pancasila yang menandakan kawasan ini memiliki sejarah serta asal-usul yang masih dipertahankan hingga sekarang.

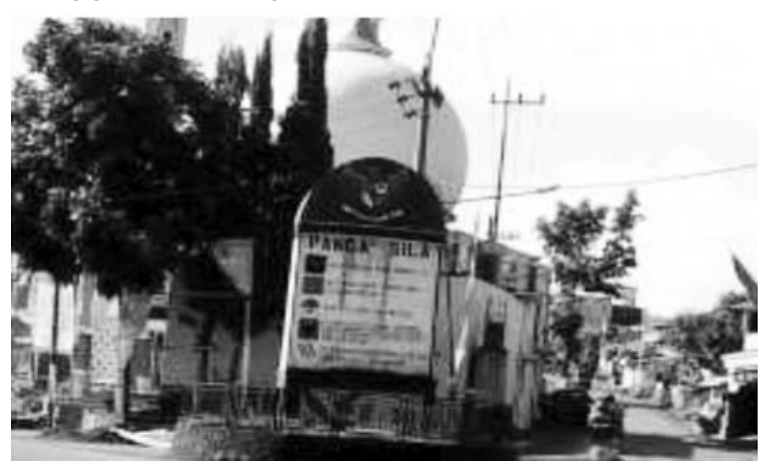

Gambar 3. Landmark

\section{Paths (jalur)}

Jalan Oro-oro ombo dikategorikan sebagai path, karena merupakan sebuah jalur akses utama yang menghubungkan pusat kota. Path pada koridor ini terdapat terdapat taman hijau sepanjang jalan, yang berfungsi sebagai peneduh. Jalan Primer memiliki lebar 6 meter dengan material aspal. Jalan Sekunder dengan lebar 4 meter, dan gang memiliki lebar 2 meter dengan material paving.

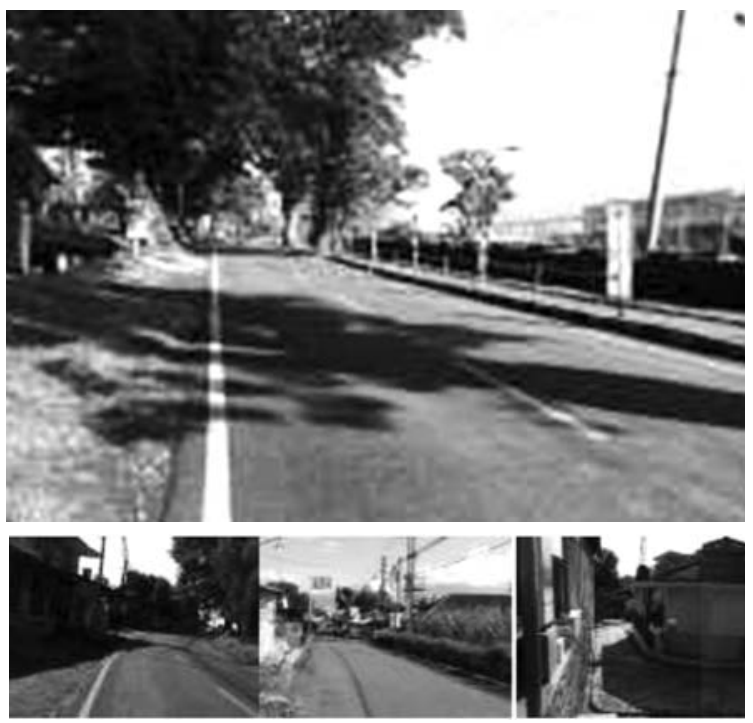

Gambar 4. Path

\section{Nodes (Simpul)}

Nodes merupakan sebuah titik konsentrasi dimana transportasi memecah. Pada kawasan ini terdapat persimpangan lalu lintas dan jembatan yang dapat dijadikan note.

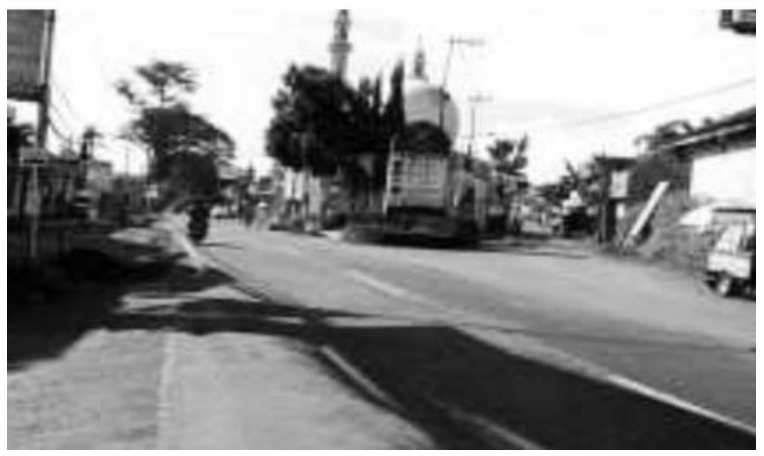

Gambar 5. Nodes 


\section{Edge (tepian)}

Edge merupakan pengakhiran dari sebuah district atau batasan sebuah district dengan yang lainnya. Edge pada kawasan ini ditandai dengan lahan kosong dan penanda tertulis.

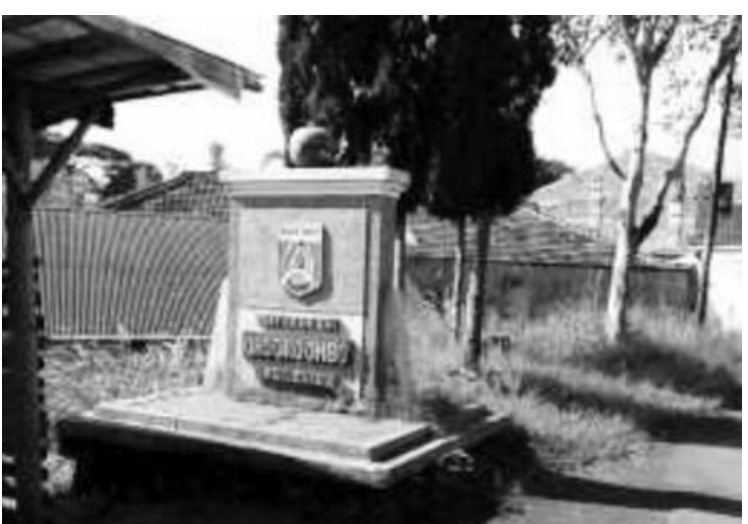

Gambar 6. Edge

\section{District (Kawasan)}

Distrik dapat dikenali karea adanya suatu karakteristik dalam suatu kawasan ini. Distrik pada kawasan ini memiliki yang berbeda dengan yang lain. Terdapat daerah komersial kegiatan ekonomi yaitu, tempat wisata, penyedia jasa penginapan dan kuliner.

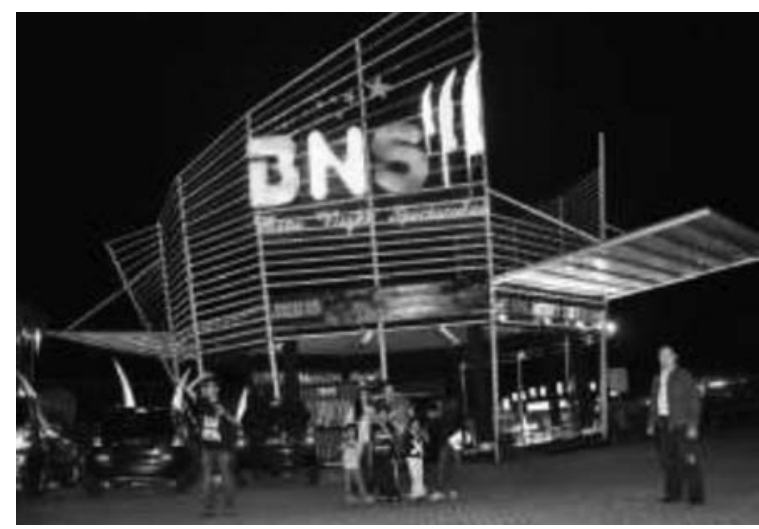

\section{Analisis dan Konsep Kawasan secara \\ Keseluruhan (Aspek Fisik) \\ Morfologi Kawasan (Makro)}

Permukiman Sebelum tahun 2008



Perubahan saat ini dan akan terus berkembang.

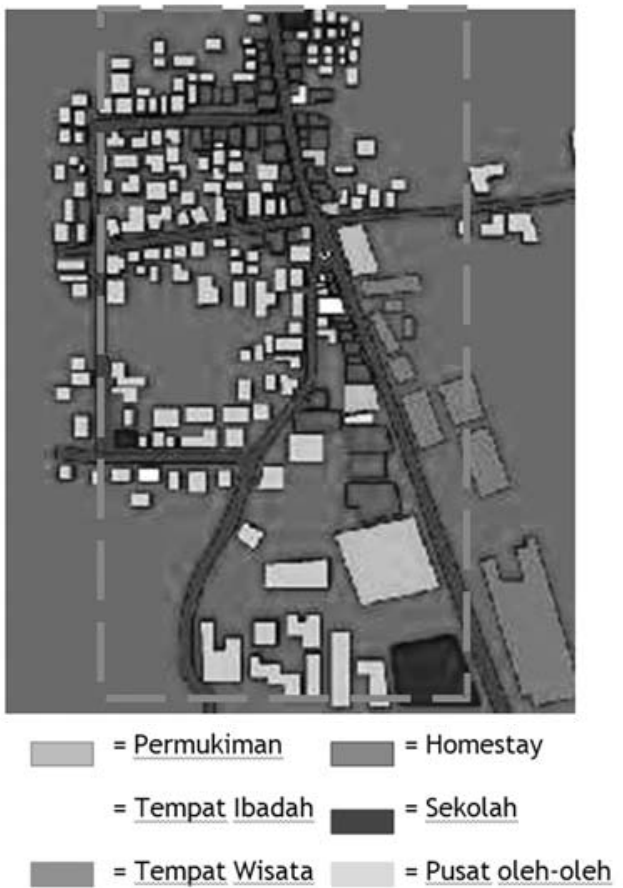


Permukiman di Oro-oro ombo memiliki pola hunian mengelompok tidak berorientasi. Pola hunian tersebut terbentuk karena sebagian besar tempat tinggal/ rumah utama yang menghadap jalan utama dijadikan tempat penginapan bagi wisata dan ruang perekonomian di sekitar hunian. Ruang perekonomian di sekitar hunian menjadi ruang aktivitas bagi masyarakat terutama yang mendukung kegiatan ekonomi. Pola tersebut banyak dijumpai pada hunian yang berlokasi langsung dengan jalan utama. Dengan melihat pola hunian yang ada di lingkungan permukiman di Oro-oro ombo dapat bahwa orientasi pemilik huni- an yang sepenuhnya mengutamakan jalan sebagai poros ekonomi.

\section{Tipo-Morfologi dalam Ruang Mikro}

Sesuai perkembangan wisata yang ada, muncul pula rumah usaha (homestay) yang semula hanya berupa rumah hunian. Perubahan fungsi rumah yang terjadi menyebabkan housing adjustment pada penghuni rumah dengan melakukan penambahan ruang. Terdapat tiga buah sampel homestay yang diambil yang terletak di satu koridor.

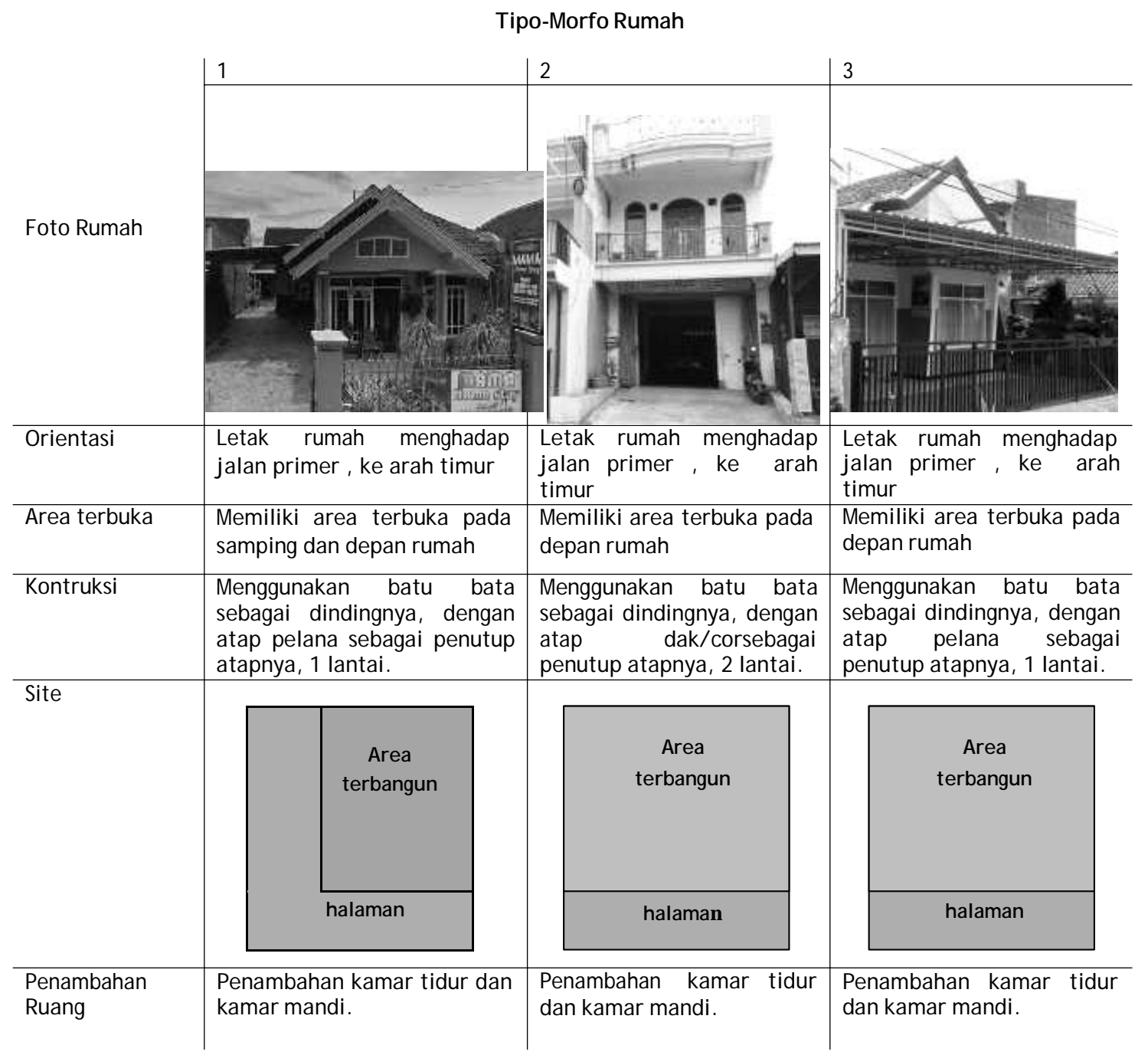




\section{Tipo-morfologi Kawasan dan Permukiman Desa Oro-Oro Ombo Kota Batu}

Budi Tri Wijaya

Warga yang semula sebagai petani menjadi memiliki pekerjaan sampingan sebagai penyewaan jasa penginapan dengan merubah fungsi rumah hunian menjadi rumah usaha (homestay).

Dengan berubahnya fungsi rumah tersebut akibat kebutuhan ekonomi, maka berubah pula tata ruang rumah. Hal ini dapat dilihat dari penambahan ruang dan pergeseran organisasi ruang seperti area publik yang semakin luas dan area privat terdesak ke belakang yang menimbulkan adanya komersialisasi ruang. Pemilik rumah memanfaatkan ruangan yang ada untuk menghasilkan uang dengan tidak terlalu mementingkan bahwa posisi mereka akan terdesak ke area belakang rumah dan privasi mereka akan terganggu.

\section{Aspek Non Fisik}

\section{Sosial Ekonomi}

Dengan berkembangnya Desa oro- oro ombo akan meningkat pula perekonomian masyarakat. Perkembangan wisata di Desa ini sejalan dengan bertambahnya fasilitas wisata yang ada. Lahanlahan kosong yang dekat dengan objek wisata dimanfaatkan untuk membangun sarana seperti warung makan, toko, dan penyewaan jasa penginapan atau sekedar menjadi lahan parkir. Desa Orooro ombo yang awalnya berkarakteristik masyarakat agraris mengalami perubahan sebagai akibat industralisasi pariwisata.

Masyarakat yang semula hanya bekerja sebagai petani, akibat adanya pekerjaan sampingan sebagai penyedia jasa penginapan dan calo, perekonomian keluarga pun meningkat.

\section{Sosial Budaya}

Sifat gotong royong di Desa Oro-oro ombo ini masih kuat. Warga bekerja sama dalam menjaga, mengembangkan dan memperbaiki fasilitas wisata. Dengan adanya banyak objek wisata pada Desa Oro-oro ombo ini tidak menimbulkan konflik, mereka mengelola usaha tersebut dengan saling rukun dan berdampingan dengan baik. Kerukunan ini merupakan salah satu faktor yang penting. Dengan adanya beberapa tempat penginapan sesama warga masyarakat juga saling menawarkan ke pengunjung. Hal ini juga salah satu faktor yang dapat menarik pengunjung. Meskipun perkembangan wisata maju, tetapi mereka dapat menjaga hubungan baik diantara para warga. Tatanan yang ada dalam masyarakat dapat terjaga dengan baik. Hal tersebut dapat dilihat dari adanya tradisi budaya yang diadakan setiap tahun.

\section{KESIMPULAN}

Tipomorfologi pada kawasan permukiman desa Oro-oro ombo dapat dilihat dari konteks skala makro dan mikro. Pada konteks makro kawasan yang terbentuk oleh beberapa elemen fisik. Pada konteks mikro mengalami perkembangan pada aspek fisik fungsi permukiman ini berdampak pada perkembangan rumah warga. Pada rumah usaha / homestay yang banyak melalukan penambahan ruang baik permanen maupun semi permanen. Penambahan fungsi usaha Ini dapat mengurangi ruang privat bagi pemilik dan memperbesar ruang publik bagi pengunjung.

Tipologi dan morfologi kawasan sangat dipengaruhi oleh aspek nonfisik. Aspek nonfisik tersebut yaitu sosialbudaya dan sosial ekonomi masyarakat yang menjadikan pola permukiman terbentuk. Keguyuban yang merupakan ciri khas dari masyarakat pedesaan juga mengalami perbedaan akibat adanya perubahan sikap masyarakatnya terhadap usaha wisata dapat menyebabkan keguyuban tersebut memudar jika terjadi konflik persaingan usaha. Sedangkan faktor-faktor yang mempengaruhi perubahan tata ruang desa adalah:

1. Adanya pertumbuhan perkotaan, demografi ataupun ekonomi.

2. Faktor sosial ekonomi. 
3. faktor perilaku masyarakat.

4. Kebijakan pemerintah yaitu pada lahan pertanian dijadikan objek wisata.

\section{Saran dan Rekomendasi}

Dari hasil pembahasan dan kesimpulan yang telah diuraikan, yang diperoleh dari karakteristik kawasan dan elemen pembentuknya. Rekomendasi dari pembahasan tersebut berkenaan tentang perlu adanya kesadaran dari masyarakat dan kebijakan pemerintah tentang kawasan tersebut. Perilaku masyarakat yang kurang memahami aturan-aturan dalam pem- bangunan sesuai dengan peraturan daerah. Penataan kawasan perlu diperhati - kan dengan berbagai pertimbangan, Seperti kenyamanaan bagi masyarakat maupun pengunjung wisata. Masyarakat juga diharapkan mampu merubah pola pikir yang lebih mengutamakan sosial ekonomi tanpa memperhatikan lingkungan dalam penataannya.

\section{Daftar Pustaka}

Adita Brigita Sekar. 2014. Transformasi Spasial Rumah Tinggal Lokal Menjadi Homestay di Surakarta. UPT Perpustakaan ISI Yogyakarta.

BadanPusat Statistik. 2015. Statistik Daerah Desa Oro-oro ombo 2015. Batu: Badan Pusat Statistik (batukota.bps.go.id/)
Dewi A, Antariksa, San Soesanto. 2005. Pengaruh Kegiatan Berdagang \Terhadap Pola Ruang Dalam Bangunan Rumah Toko Di Kawasan Pecinan Kota Malang. Dimensi Teknik Arsitektur. Vol 33 No.1

Fajari Safinta Rhosa, Atiek Suprapti, Bambang Supriyadi. 2014. Pengaruh Terhadap Perubahan Tata Ruag Desa dan Tata ruang Rumah Tinggal. Jurnal Tesa Arsitektur , Vol 12 No.2

Kinskij Yohannes, Antariksa, Fadly Usman. 2010. Pelestarian Bangunan dan Lingkungan di Jalan Panglima Sudirman Kota Batu.Arsitektur e-Journal, Vol: 3 No.2

Nurfansyah. 2012. Tipologi kawasan jalan Pageran Antasari Banjarmasin. Banjarmasin: Info Teknik

Pemerintahan Kota Batu. 2010. Rencana Tata Ruang Wilayah Kota Batu 2010- 2030. Batu: Pemkot Batu

Purwanto E. 2010. Pendekatan Pemahaman Citra Lingkungan Perkotaan. Jurnal teknik Arsitektur

Rudiansyah. 2013. Tipologi dan Makna Simbolis Rumah Tjong A Fie. Jakarta : Estilisium

en.wikipedia.org/wiki/Oro-oro Ombo,_Indonesia google.co.id/maps/place/Oro-oro ombo,+Batu+Sub-D 